\title{
Zbigniew Babicki
}

ORCID: 0000-0002-0857-3132

Uniwersytet Kardynała Stefana Wyszyńskiego w Warszawie

\section{Rodzina w świetle Karty Praw Rodziny}

\begin{abstract}
Family in the light of the Charter of Family Rights
\section{Abstract}

The Charter of the Rights of the Family presents a succinct Christian viewpoint on a number of the most important problems of family life. By assumption, it is addressed primarily to governments representing various cultures, which take responsibility for the common good, model and point of reference for building appropriate legislation and family policy, as well as setting directions for specific actions. The Charter includes provisions on ensuring families with appropriate moral, educational, social and economic conditions. The Charter explicitly emphasizes the right of parents to educate their children in accordance with their moral and religious beliefs, taking into account the cultural traditions of the family, and to decide on the education of their children. It is an important document which indicates the direction of (re) building the legal and mental system of society in the approach to the institution of the family in the light of the social teaching of the Church. The aim of the article is to try to show the topicality of the Charter of Family Rights in the life of a modern family and the functioning of the state. The text focuses on selected areas related to the fundamental rights of the family, its identity, the family as an educational environment and the need for appropriate support and help for the family.
\end{abstract}

\section{Keywords}

the family, the Charter of the Rights of the Family, the rights of the family, the social teaching of the Church

\section{Wstęp}

Karta Praw Rodziny powstała z inspiracji synodu biskupów zebranego w Rzymie w 1980 r. W odpowiedzi na tę inicjatywę papież Jan Paweł II w adhortacji apostolskiej Familiaris consortio, rozwijając ten temat, zobowiązał Stolicę Apostolską do opracowania Karty Praw Rodziny (KPR) w celu przedłożenia jej zainteresowanym środowiskom i władzom ${ }^{1}$. Opublikowana w 1983 r. KPR nie jest wykładem teologii

\footnotetext{
${ }^{1}$ Jan Paweł II, Familiaris consortio, [w:] T. Styczeń (red.), Tekst i komentarze, Lublin 1987, s. 54.
} 
dogmatycznej i moralnej na temat instytucji małżeństwa i rodziny, chociaż ukazuje w tej kwestii stanowisko Kościoła. Nie jest również zwykłą deklaracją teoretycznych zasad postępowania w życiu rodzinnym. Dokument ten stawia sobie za cel przedstawienie wszystkim ludziom dobrej woli najpełniejszego i usystematyzowanego ujęcia podstawowych praw rodziny jako naturalnej i powszechnej społeczności. W szczególny sposób KPR jest adresowana do instytucji rządowych, które ze względu na swoje kompetencje i odpowiedzialność mają obowiązek stać na straży praw człowieka oraz nie powinny godzić się na łamanie podstawowych praw rodziny. Karta Praw Rodziny w swojej podstawowej wymowie odwołuje się do Powszechnej Deklaracji Praw Człowieka ogłoszonej 10.12.1948 roku przez Organizację Narodów Zjednoczonych. Zgodnie z Deklaracją „rodzina jest naturalną i podstawową komórką społeczeństwa i ma prawo do ochrony ze strony społeczeństwa i Państwa”2. KPR stanowi pogłębioną i rozwiniętą analizę zagadnienia, które zostało już podjęte w $D e-$ klaracji ONZ ${ }^{3}$. O znaczeniu rodziny w życiu społecznym może świadczyć także fakt, że w 1994 r. ustanowiony w Kościele „Rok Rodziny” był obchodzony równocześnie z ogłoszonym przez Organizację Narodów Zjednoczonych „Międzynarodowym Rokiem Rodziny". W odpowiedzi na to wydarzenie polski parlament przyjął rezolucję w sprawie Międzynarodowego Roku Rodziny, w której czytamy:

Sejm Rzeczypospolitej Polskiej, w związku z ogłoszeniem przez Organizację Narodów Zjednoczonych roku 1994 Międzynarodowym Rokiem Rodziny, pragnie zainteresować społeczeństwo, Radę Ministrów i samorząd terytorialny problemami związanymi z zaspokajaniem potrzeb i prawidłowym rozwojem emocjonalnym, umysłowym i fizycznym dzieci i młodzieży.

Sejm Rzeczypospolitej Polskiej wzywa Radę Ministrów do opracowania Raportu o sytuacji polskiej rodziny w terminie do 31 marca 1995 r. Dokument ten powinien stanowić istotną część informacji o stanie naszego społeczeństwa.

Raport i debata sejmowa powinny stać się inspiracją dla opracowania programu zawierającego działania rządowe i pozarządowe na rzecz polskiej rodziny.

Uważamy, że problemy rodzin, a w szczególności działanie na rzecz prawidłowego emocjonalnego, umysłowego i fizycznego rozwoju dzieci i młodzieży, mogą i powinny stać się płaszczyzną współdziałania Rady Ministrów, pozarządowych organizacji społecznych i politycznych oraz kościołów i związków wyznaniowych $(\ldots)^{4}$.

2 Powszechna Deklaracja Praw Człowieka, art. 16, https://www.unesco.pl/fileadmin/user_upload/pdf/Powszechna_Deklaracja_Praw_Czlowieka.pdf [dostęp: 16.08.2021].

${ }^{3}$ Karta Praw Rodziny. Prezentacja, interpretacja i komentarz J.E. Biskup Vincenzo Paglia - przewodniczący Papieskiej Rady ds. Rodziny, Pelplin 2013, s. 5.

${ }^{4}$ Rezolucja Sejmu Rzeczypospolitej Polskiej z dnia 27 października 1994 r.w sprawie Międzynarodowego Roku Rodziny, https://sip.lex.pl/akty-prawne/mp-monitor-polski/miedzynarodowy-rok-rodziny-16824844 [dostęp: 14.09.2021]. 
Rodzina stanowi przedmiot badań wielu dyscyplin naukowych ze względu na to, że jest zarówno podstawową grupą społeczną, jak i instytucją wychowującą nowe pokolenia. Bez względu na różnego rodzaju uwarunkowania natury społecznej, ekonomicznej czy politycznej jest wyjątkową wspólnotą osób, która przede wszystkim ma charakter życiodajny - przekazuje życie. Rodzina jest środowiskiem kształtowania osobowości, transmisji określonych norm, wartości i obyczajów, przekazywania postaw i zachowań, wrastania w społeczeństwo oraz kulturę.

Celem artykułu jest próba ukazania wizji rodziny w świetle Karty Praw Rodziny. Dla Kościoła katolickiego rodzina i wychowanie stanowią dwie ściśle ze sobą związane rzeczywistości. Kościół stoi na stanowisku, że rodzina i rodzicielstwo są wpisane przez Boga w naturę człowieka. Ujmuje rodzinę w kategoriach daru, pełnego siły, dynamizmu rozwojowego, a jednocześnie ofiarności, wysiłku na rzecz drugiej osoby. Z tego środowiska wyrastają dzieci, członkowie rodziny i społeczeństwa Kościoła i państwa. Rodzina jest najważniejszym miejscem rozwoju człowieka, kultury i państwa, dlatego wymaga odpowiedniej pomocy i wsparcia. Tekst koncentruje się na wybranych obszarach związanych z podstawowymi prawami rodziny, jej tożsamości, rodziny jako środowiska wychowawczego oraz potrzeby odpowiedniego wsparcia i pomocy rodzinie. $\mathrm{W}$ dyskursie nad kondycją i miejscem rodziny w społeczeństwie pluralistycznym powinno być miejsce dla stanowiska Kościoła w tej kwestii. Ten artykuł stara się wypełnić tę przestrzeń i przybliżyć problematykę KPR.

\section{Podstawowe prawa rodziny w świetle KPR}

Wielu badaczy dostrzega zjawisko globalnego ataku na instytucję małżeństwa i rodziny w świecie współczesnym. Rzeczą niemożliwą jest dokonanie w tym artykule pełnego zobrazowania tych zjawisk, które godzą w rodzinę lub które wg opinii niektórych - są przejawem powolnego zmierzchu instytucji rodziny. Christine de Marcellus Vollmer, założycielka i prezes Alliance for the Family ${ }^{5}$ przekonuje, że atak na rodzinę przybiera dzisiaj formę wojny wypowiedzianej

\footnotetext{
${ }^{5}$ Christine de Marcellus Vollmer jest członkiem Papieskiej Rady ds. Rodziny i członkiem założycielem Papieskiej Akademii Życia. W latach 1990-1995 była członkiem delegacji Stolicy Apostolskiej przy ONZ. Jako przewodnicząca Światowej Organizacji na rzecz Rodziny i członek Komitetów Planowania Światowego Kongresu Rodzin Christine de Marcellus Vollmer organizowała konferencje na temat rodziny w całej Europie i Ameryce Łacińskiej. W 2010 r. otrzymała nagrodę Global Leadership Award, uznanie za jej wpływ na międzynarodowy ruch prorodzinny i element jednoczący między grupami religijnymi w obronie naturalnej rodziny. Od 1984 roku, w ramach Alliance for the Family, zespół kierowany przez Christine de Marcellus Vollmer opracował własną pedagogię, aby skutecznie uczyć dzieci i młodzież wartości, cnót i umiejętności niezbędnych do udanego życia małżeńskiego i rodzinnego. Ta nowa pedagogia skoncentrowana na programie nauczania „Żyjący
} 
instytucji rodziny, jej roli, wartości i świętości. Zaś nieodłącznym elementem wojny jest śmierć, wskutek czego powstaje cywilizacja śmierci. W opinii przywołanej myślicielki można wyodrębnić dwa główne wektory tej wojny: prokreacja i moralność seksualna. Swoje przekonania opiera na analizie zjawisk występujących w USA, które destrukcyjnie wpływają na kondycję rodziny. Należą do nich: deprawacja dzieci i młodzieży w ramach tzw. edukacji seksualnej, podważanie podstaw instytucji rodziny, którymi są przekazywanie życia i miłość, w wyniku lansowania antykoncepcji i aborcji. Jako kolejne działanie uderzające w rodzinę autorka wskazuje na zjawisko niszczenia autorytetu ojcostwa i propagowanie samotnego macierzyństwa. Przekonuje, że macierzyństwo w cywilizacji śmierci przedstawiane jest jako nowoczesna forma niewolnictwa, poniżająca godność kobiety. Do zagrożeń godzących w instytucję rodziny Ch. de Marcellus Vollmer zalicza także działania różnych środowisk, organizacji, które oddzielają płeć biologiczną od tzw. płci kulturowej'

Prawa rodziny zawarte w KPR odnoszą się do fundamentalnych zagadnień, które odpowiadają na pytania: kim jest człowiek i czym są wspólne wartości całego rodzaju ludzkiego. Rodzina w świetle KPR jest społecznością osób, które są ze sobą we właściwy sobie sposób, czyli komunii (communio personarum). Rodzina bierze swój początek w małżeństwie jako wspólnocie kobiety i mężczyzny, którzy przyjmują się wzajemnie oraz sobie służą. Oznacza to, że małżeństwo jest rozumiane jako komunia dwojga osób, tzn. „ja” i „ty”. Zaś pojęcie wspólnoty wskazuje na poszerzenie tej relacji w stronę społeczności - „my”. Rodzina widziana w tej optyce staje się wspólnotą osób i jednocześnie pierwszą grupą społeczną ${ }^{7}$. W związku $\mathrm{z}$ tym zadaniem społeczeństwa jest obrona praw rodziny przed jakimkolwiek ich naruszeniem i tworzeniem takiego prawodawstwa, które pozwoli rozwijać politykę prorodzinną. KPR z założenia jest skierowana zwłaszcza do rządów reprezentujących różne kultury, które podejmują odpowiedzialność za wspólne dobro, model oraz punkt odniesienia dla zbudowania odpowiedniego ustawodawstwa i polityki rodzinnej, a także wyznaczenia kierunków konkretnych działań. KPR adresowana jest także do samych rodzin w celu umocnienia w nich świadomości niezbywalnej roli i miejsca $\mathrm{w}$ życiu indywidualnym oraz społecznym. Zachęca do łączenia sił dla podejmowania działań na rzecz obrony swoich praw, aby, mając na względzie obecne i przyszłe dobro ludzkości, umacniać instytucję rodziny. KPR w swoim przesłaniu jest wreszcie apelem skierowanym do wszystkich członków Kościoła,

dla Świata" ma charakter międzynarodowy i została przyjęta przez ludzi wszystkich wyznań, https:// doc-research.org/speaker/christine-de-marcellus-vollmer/ [dostęp: 06.10.2021].

${ }^{6}$ B. Mierzwiński, Quo vadis familia? Cywilizacja śmierci zagrożeniem rodziny i społeczeństwa, [w:] M. Ozorowski, A. Skreczko (red.), Kościół. Rodzina. Życie, Warszawa 2011, s. 81.

${ }^{7}$ K. Wojtyła, Rodzina jako „communio personarum”. Próba interpretacji teologicznej, „Ateneum Kapłańskie" 1974, nr 66 (83), s. 355. 
aby dawali świadectwo, że nic nie jest w stanie zastąpić rodziny jako naturalnego środowiska rozwoju człowieka ${ }^{8}$.

Jak zauważył były marszałek Senatu RP Andrzej Stelmachowski, Karta Praw Rodziny stanowi zupełnie inny dokument niż wcześniejsze dokumenty z zakresu społecznej nauki Kościoła. Dokument ten jest ujęty w sposób, w jaki ujmuje się konwencje międzynarodowe. Pomimo swojej zwięzłości, ponieważ zawiera zaledwie 12 artykułów, ma swoją preambułę, która jest podobna do preambuł konwencji międzynarodowych. KPR przedstawia skondensowany chrześcijański punkt widzenia na szereg najważniejszych problemów życia rodzinnego. W tym krótkim dokumencie zawarto sprawy, które „dotyczą »wnętrza« rodziny, a więc stosunków między osobami sobie najbliższymi, między małżonkami, rodzicami i dziećmi, jak i stosunków, które się kształtują w wyniku »awarii« rodzin, wreszcie tych, które pozostają na peryferiach rodziny, ale kształtują i bardzo często warunkują jej warunki życia. Można tylko powiedzieć, jak to się stało, że zdołano w 12 artykułach objąć to, czego nie są w stanie udźwignąć rozbudowane kodeksy obowiązujące w poszczególnych krajach"”.

Można postawić pytanie, jakie zadania stawia KPR przed współczesnymi ludźmi, zwłaszcza świeckimi katolikami? Wydaje się, że na wzór dwunastu artykułów KPR można sformułować dwanaście problemów, z których jedne są bardziej palące, inne mniej. Trzeba jednak pamiętać, że Karta ma charakter uniwersalny, dotyczący różnych krajów, różnych kultur i podejmuje próbę odpowiedzi na zróżnicowane potrzeby. Możemy zatem przedstawić następujący katalog praw rodziny wynikających z KPR:

- prawo do zawarcia małżeństwa i założenia rodziny oraz do odpowiednich warunków w celu jej utrzymania;

- prawo do wolności religijnej;

- prawo do posiadania potomstwa i wychowania go zgodnie z własnymi przekonaniami religijnymi, moralnymi i poszanowaniem tradycji kulturowych, które sprzyjają dobru i godności dziecka;

- prawo do pomocy ze strony społeczeństwa, zwłaszcza rodzinom wielodzietnym co do wychowania dzieci i opieki nad nimi;

- prawo do swobodnego wyboru szkoły zgodnie z własnymi przekonaniami. W szczególności dotyczy to edukacji seksualnej jako podstawowego prawa rodziców;

- prawo do niezależności, integralności i stałości rodziny;

\footnotetext{
8 Karta Praw Rodziny, op. cit., s. 10-12.

9 A. Stelmachowski, Karta Praw Rodziny, [w:] K. Majdański (red.), Tak - życiu, tak - prawdzie, Łomianki 1991, s. 21.
} 
- prawo do swobodnego organizowania życia religijnego, uczestnictwa w kulcie publicznym i wyboru programów wychowania religijnego;

- prawo do zrzeszania się z innymi rodzinami i instytucjami w celu właściwego wypełniania swoich zadań oraz dla ochrony praw rodziny;

- prawo do polityki rodzinnej w kwestiach prawnych, gospodarczych, spolecznych, finansowych;

- prawo do takiego systemu społeczno-gospodarczego, w którym organizacja pracy umożliwi członkom rodziny wspólne życie i nie zagrozi jedności, stabilności, zapewniając równocześnie możliwość zdrowego wypoczynku;

- prawo do mieszkania odpowiedniego dla życia rodzinnego i dostęp do podstawowych usług życia rodzinnego i społecznego;

- prawo do emigrowania rodzin. Rodziny imigrantów mają prawo do poszanowania własnej kultury i do wsparcia oraz koniecznej opieki w celu lepszej integracji ${ }^{10}$.

Mimo że od opublikowania Karty Praw Rodziny pod redakcją Papieskiej Rady ds. Rodziny minęło już 38 lat, to nie straciła ona na swojej aktualności. Przeciwnie, wszystkie wskazania w niej zawarte zachowują swoją wagę i siłę argumentacji poruszanych problemów. Po pierwsze, Karta jasno określa tożsamość i istotę rodziny jako środowiska rozwoju dziecka. Po drugie, stanowi niezwykle waży apel, zachętę skierowaną do rządów, międzynarodowych organizacji odpowiedzialnych za tworzenie polityki prorodzinnej i odpowiednich programów do wzmocnienia zaangażowania na rzecz obrony praw rodziny oraz umocnienia i wsparcia instytucji rodziny. Watykan, ogłaszając KPR, zwrócił się także do wszystkich instytucji kościelnych i w ogóle do wszystkich członków Kościoła, aby starali się zapewnić rodzinom potrzebne wparcie w wypełnianiu ich zadań.

\section{Tożsamość instytucji rodziny}

Rodzina w dzisiejszych czasach znajduje się w zasięgu rozległych i szybkich przemian społecznych i kulturowych. Kościół katolicki w Polsce dostrzega negatywne zjawiska dotykające współczesne polskie rodziny, dzieląc je na dwie grupy. Do pierwszej zalicza zagrożenia w obszarze podstawowych celów małżeństwa i rodziny: rozwody, wolne związki, deprecjonowanie rodzicielstwa, brak szacunku dla życia ludzkiego od poczęcia. Do tego można jeszcze dodać alkoholizm, narkomanię i inne uzależnienia degradujące środowisko rodzinne. Do drugiej grupy zalicza zagrożenia natury społeczno-gospodarczej, takie jak: pomniejszanie społecznej roli rodziny, ubóstwo wielu rodzin, niedobory mieszkaniowe, bezrobocie itp. Kościół

${ }^{10}$ Karta Praw Rodziny, op. cit., s. 18-36. 
świadomy tego, że rodzina jest jednym z najcenniejszych dóbr ludzkości, pragnie nieść swoją naukę i zaoferować pomoc tym, którzy tego potrzebują. Kościól, jak głosi Sobór Watykański II, zna wartość rodziny i rozumie, że dobro społeczeństwa i jego własne związane jest $\mathrm{z}$ dobrem rodziny ${ }^{11}$. KPR jest wyrazem myśli Kościoła w kwestii znaczenia rodziny w życiu każdego człowieka i społeczeństwa. W rozumieniu Kościoła rodzina została utworzona jako „głęboka wspólnota życia i miłości” ${ }^{12}$. Dlatego też istota i zadania rodziny są w ostateczności formułowane przez miłość. Jan Paweł II w Familiaris consortio głosi, że rodzina otrzymuje „misję strzeżenia, objawiania i przekazywania miłości, będącej żywym odbiciem i rzeczywistym udzielaniem się miłości Bożej”'13. Papież, analizując aspekt społeczny rodziny, podkreśla, że jako wspólnota osób jest najmniejszą „komórką” społeczną. Tym samym oznacza to, że jest podstawową instytucją życia każdego społeczeństwa. Czego zatem instytucja rodziny może oczekiwać od państwa? W ocenie papieża rodzina

oczekuje przede wszystkim uznania swej tożsamości i zaakceptowania jako społeczna podmiotowość. Podmiotowość jest związana z tożsamością każdego małżeństwa i rodziny. Małżeństwo, leżące u podstaw instytucji rodzinnej, ustanowione jest dzięki przymierzu, przez które „mężczyzna i kobieta tworzą ze sobą wspólnotę całego życia, skierowaną ze swej natury do dobra małżonków oraz do zrodzenia i wychowania potomstwa". Tylko taki związek może być uznany i potwierdzony społecznie jako „małżeństwo”. Nie mogą być uznane społecznie jako małżeństwo inne związki międzyludzkie, które tym warunkom nie odpowiadają, choć dzisiaj istnieją takie tendencje, bardzo groźne dla przyszłości ludzkiej rodziny i społeczeństw ${ }^{14}$.

Stanowisko Kościoła w kwestii tożsamości rodziny wyrażone przez Jana Pawła II jest jasne, stanowcze i konsekwentne. Mówi ono, że:

Żadne społeczeństwo ludzkie nie może ryzykować permisywizmu w sprawach tak podstawowych jak istota małżeństwa i rodziny! Tego typu permisywizm moralny w swych konsekwencjach musi szkodzić samemu społeczeństwu, jego autentycznej spoistości społecznej i humanistycznej. Jest więc rzeczą zrozumiałą, że Kościół stoi na straży autentyczności ludzkich rodzin i wzywa odnośne instytucje, zwłaszcza parlamenty i państwa, a także organizacje międzynarodowe, ażeby nie ulegały pokusie pozornej nowoczesności ${ }^{15}$.

${ }^{11}$ Gaudium et spes, [w:] Sobór Watykański II. Konstytucje, dekrety, deklaracje, Poznań 1967, s. $575-576$.

12 Ibidem, s. 576.

${ }^{13}$ Jan Paweł II, Familiaris consortio, op. cit., s. 25.

${ }_{14}$ Jan Paweł II, List do Rodzin, Rzym 1994, s. 18-19, http://kodr.pl/wp-content/uploads/2017/03/ list_do_rodzin.pdf [dostęp: 30.08.2021].

${ }^{15}$ Ibidem, s. 19. 
Rodzina jako wspólnota miłości i życia jest społecznością najmocniej „ugruntowaną" i w sposób sobie właściwy społecznością suwerenną, choć równocześnie jest to społeczność wielorako uzależniona. Zarówno zasada suwerenności instytucji rodziny, jak też fakt wielorakich uzależnień pozwala mówić o prawach rodziny. Prawa rodziny wskazują na szczególną bliskość w relacji do praw człowieka. Skoro bowiem rodzina jest komunią osób, jej autorealizacja zależy w znacznej mierze od tego, czy są przestrzegane prawa każdej osoby ludzkiej, która ją stanowi. Wśród tych praw niektóre dotyczą wprost rodziny, jak np. prawo małżonków do rodzicielstwa, czy też do wychowania swoich dzieci, inne zaś odnoszą się do rodziny w sposób pośredni ${ }^{16}$. Nauczanie Kościoła, zwłaszcza Deklaracja o wychowaniu chrześcijańskim Soboru Watykańskiego II Gravissimum educationis, podkreśla fundamentalne miejsce środowiska rodzinnego w rozwoju dziecka. Przedstawiony w tym dokumencie ideał chrześcijańskiego wychowania podkreśla, że powinien on być realizowany przez wszystkich ludzi odpowiedzialnych za chrześcijańskie wychowanie dziecka, w szczególny zaś sposób ma dynamizować wychowawcze działania rodziców. „Do rodziców bowiem należy stworzyć taką atmosferę rodzinną, przepojoną miłością i szacunkiem dla Boga i ludzi, aby sprzyjała całemu osobistemu i społecznemu wychowaniu dzieci. Dlatego rodzina jest pierwszą szkołą cnót społecznych, potrzebnych wszystkim społecznościom"17. Ten najważniejszy dokument Kościoła w kwestii wychowawczej roli środowiska rodzinnego jasno określa relacje instytucji rodziny do państwa, co jest zgodne z obowiązującą Konstytucją RP. Obowiązek wychowania dzieci spoczywa w pierwszym rzędzie na rodzinie, która potrzebuje wsparcia całej społeczności. Dlatego oprócz

praw rodziców i tych, którym oni powierzają część zadania wychowawczego, pewne obowiązki i prawa przysługują państwu, ponieważ do niego należy organizowanie tego, czego wymaga wspólne dobro doczesne. Do jego zadań należy popieranie różnymi sposobami wychowania młodzieży, a mianowicie: ochrona obowiązków i praw rodziców oraz innych, którzy mają udział w wychowaniu, i dopomaganie im; przejmowanie wedle zasady pomocniczości wychowania w wypadku braku inicjatywy ze strony rodziców i innych społeczności, lecz z uwzględnieniem życzeń rodziców ${ }^{18}$.

Równocześnie prawa rodziny nie są tylko matematyczną sumą praw osoby. Rodzina bowiem jest czymś więcej niż każdy z osobna człowiek. Jest wspólnotą rodziców i dzieci, bywa nieraz wspólnotą wielu pokoleń. Dlatego też jej podmiotowość domaga się własnych specyficznych praw. Podmiotowość kształtuje się przede

16 Ibidem.

${ }_{17}$ Deklaracja o wychowaniu chrześcijańskim, [w:] Sobór Watykański II. Konstytucje, dekrety, deklaracje, Poznań 1967, s. 316.

18 Ibidem. 
wszystkim na bazie zasad moralności. Karta Praw Rodziny, wychodząc od tych zasad, ugruntowuje bytowanie rodziny w porządku społeczno-prawnym „wielkiego" społeczeństwa, a więc przede wszystkim narodu, z kolei państwa, a także wspólnot międzynarodowych. Każde z tych „wielkich” społeczeństw jest uwarunkowane bytem rodziny, przynajmniej pośrednio. Określenie zadań i obowiązków „wielkiego” społeczeństwa w stosunku do rodziny jest sprawą niezwykle doniosłą ${ }^{19}$.

Papież Franciszek w encyklice Lumen fidei określa rodzinę jako trwały związek kobiety i mężczyzny w małżeństwie powstały z miłości. $\mathrm{W}$ tej relacji małżonkowie są gotowi do ponoszenia wyrzeczeń i ofiary dla siebie nawzajem. Zdaniem papieża wiara w Boga przeżywana i pogłębiana we wspólnocie rodzinnej ma wpływ na wszystkie relacje społeczne, buduje postawy braterstwa i przyjaźni ${ }^{20}$.

Rodzina, w rozumieniu Franciszka, jest szkołą empatii i altruizmu, ponieważ kształtuje postawę odpowiedzialności za siebie i innych. Rodzina otwarta na innych ludzi staje się środowiskiem oddziaływania wychowawczego. Uczy przezwyciężać indywidualistyczną mentalność, którą nasycona jest współczesna zachodnia cywilizacja. Papież Franciszek, podobnie jak jego poprzednicy, wzywa wszystkich ludzi dobrej woli do wspierania i promowania rodziny, podkreślając jej fundamentalną rolę w życiu społecznym, umacniania ładu społecznego i państwowego opartego na zasadzie solidarności społecznej ${ }^{21}$. Franciszek, nawiązują do wypowiedzi Jan Pawła II, przypomina, że rodzina jest „wspólnotą osób”, miejscem, w którym człowiek uczy się kochać. Nadaje tej podstawowej wspólnocie ważną funkcję aktywizacyjną życia społecznego. Twierdzi bowiem, że dzieci, przebywając z rodzicami, rodzeństwem i innymi członkami rodziny, kształtują swoją osobowość. Środowisko rodzinne jest przestrzenią wymiany uczuć, nauki dialogu i komunikacji międzyludzkiej. Rodzina jest wreszcie miejscem, w którym osobie zostaje nadane imię, przez co człowiek nabiera świadomości własnej godności ${ }^{22}$.

W Preambule KPR sformułowany został pogląd, że „rodzina zbudowana jest na małżeństwie, głębokim i uzupełniającym się związku mężczyzny i kobiety, który opiera się na nierozerwanej więzi małżeństwa zawartego dobrowolnie i publicznie, otwartego na przekazywanie życia"23. Małżeństwo jako związek kobiety i mężczyzny, rodzina, macierzyństwo i rodzicielstwo znajdują się także pod ochro-

19 Ibidem.

${ }^{20}$ Franciszek, Encyklika Lumen fidei, Rzym 2013, s. 73-74, https://www.vatican.va/content/ $\mathrm{dam} /$ francesco/pdf/encyclicals/documents/papa-francesco_20130629_enciclica-lumen-fidei_ pl.pdf. [dostęp: 31.08.2021].

${ }^{21}$ Franciszek, Solidarność między pokoleniami. Przesłanie z okazji 47. Tygodnia Społecznego Katolików Włoskich, „L'Osservatore Romano” 2013, nr 11 (34), s. 33-34.

22 Franciszek, W rodzinie uczymy się kochać i bronić życia. Audiencja dla uczestników zgromadzenia plenarnego Papieskiej Rady ds. Rodziny z 25 października 2013 r., "L'Osservatore Romano” 2013, nr 12 (34), s. 27.

${ }^{23}$ Karta Praw Rodziny, op. cit., s. 14. 
ną i opieką Rzeczypospolitej Polskiej²4. W dniu 21 października 2016 r. Sejm Rzeczypospolitej Polskiej podjął uchwałę w sprawie ustanowienia Dnia Praw Rodziny. Z tej uchwały wynika, że polski parlament jest

zatroskany o przyszłość rodziny opartej na trwałym związku mężczyzny i kobiety, otwartym na przekazywanie życia i zaspokojenie podstawowych potrzeb małżonków i dzieci, ustanawia dzień 22 października Dniem Praw Rodziny.

Sejm Rzeczypospolitej Polskiej uznając, że fundament bytu i rozwoju Państwa Polskiego stanowi rodzina, zachęca wszystkich obywateli, instytucje oraz władze do stałej troski o prawa rodzin. Jednocześnie Sejm Rzeczypospolitej Polskiej wzywa wszystkie rodziny do komplementarnego wypełniania ich zadań oraz obrony i umacniania należnych im praw. Sejm Rzeczypospolitej Polskiej dołoży wszelkich starań, aby poprzez stanowienie odpowiedniego prawa, polskie rodziny mogły czuć się bezpiecznie, trwając w przeświadczeniu o stałej trosce państwa o ich byt materialny oraz wszechstronny rozwój $j^{25}$.

Zbigniew Tyszka, znany badacz polskiej rodziny wyraża przekonanie, że w dzisiejszych czasach ścierają się dwie koncepcje świata i rodziny. Z jednej strony mamy do czynienia ze światem ładu i hierarchii, z drugiej ze światem „anarchicznej wolności i buntu wobec wszelkiego porządku"26. Obserwowane zmiany w sferze gospodarczej, społecznej, kulturowej mają swoje teoretyczne ugruntowanie w różnych koncepcjach liberalizmu, które w znacznym stopniu odpowiadają za radykalną zmianę w obszarze wartości, zachowań i zasad społecznych. W odpowiedzi na takie zmiany Kościół przedstawia ugruntowaną i znaną koncepcję rodziny oraz opartą na tej instytucji wizję społeczeństwa.

\section{Rodzina jako środowisko wychowawcze}

Wychowawcza wartość rodziny wielokrotnie była w historii podważana i kwestionowana. Począwszy od czasów starożytnych aż po współczesność pojawiają się koncepcje odrywania wychowania od rodziny. Stanisław Styrna zauważa, że w XIX w. przepojeni utopijnymi ideologiami badacze deprecjonowali wychowawczą rolę rodziny. Sądzili bowiem, że w lepszym stopniu jej zadania pełnią określone zakłady opiekuńczo-wychowawcze. Pojawiały się także dążenia pomijania

${ }^{24}$ Konstytucja Rzeczypospolitej Polskiej, art. 18, https://www.sejm.gov.pl/prawo/konst/polski/ kon1.htm [dostęp: 23.08.2021].

${ }^{25}$ Uchwała Sejmu Rzeczypospolitej Polskiej z dnia 21.10.2016 r. w sprawie ustanowienia Dnia Praw Rodziny, http://isap.sejm.gov.pl/isap.nsf/download.xsp/WMP20160001003/O/M20161003.pdf [dostęp: 6.10.2021].

${ }_{26}$ Z. Tyszka, System metodologiczny wieloaspektowej integralnej analizy życia rodzinnego, Poznań 2001, s. 104. 
rodziny i możliwie szerokiego przejmowania wychowania przez instytucje publiczne $\mathrm{w}$ celu nadania mu właściwego kierunku i poziomu ${ }^{27}$. Kościół katolicki w swoim nauczaniu, przede wszystkim od czasów Leona XIII, przekonuje o znaczeniu rodziny jako środowiska wychowawczego, a zatem i o prawie rodziny do wychowania. Mieczysław A. Krąpiec, wychodząc od natury człowieka i charakteru właściwego mu rozwoju, podkreśla niezastąpioną rolę rodziny jako instytucji monogamicznej i trwałej. Twierdzi, że rodzina w wyniku szczególnego wglądu w „psychikę swych członków, poprzez długoletnie wspólne przeżywanie, poprzez wyznawane wspólne ideały, wspólne przeżycia religijne i obyczajowe - jedyna jest władna pokierować skutecznie pożądanym rozwojem człowieka"28. Wynika $\mathrm{z}$ tego, że podstawą instytucji rodziny jest właściwie rozumiana i przeżywana relacja interpersonalna oparta na miłości i szacunku, otwarta na prokreację. Stąd też działalność opiekuńczo-wychowawcza rodziców względem swoich dzieci powinna polegać na zaspokajaniu potrzeb rozwojowych we wszystkich sferach: fizycznej, intelektualnej, społecznej, emocjonalnej, moralnej, duchowej z religijną włącznie. To właśnie w tym duchu należy rozumieć istotę rodziny jako środowiska wychowawczego z punktu widzenia nauki Kościoła. W tym też duchu Kościół powołuje różne instytucje, które mają wspierać rodzinę w wypełnianiu jej zadań. Treści zaprezentowane w Karcie Praw Rodziny powinny być podstawą do formułowania praw i wskazań wychowawczych oraz sposobów ich realizacji, szczególnie przez państwo, którego obowiązkiem jest troska o wszechstronny rozwój wychowawczej funkcji rodziny, zwłaszcza w formie stosownych przepisów prawnych.

W opinii wielu badaczy współczesna rodzina przeżywa poważny kryzys. Z. Tyszka stwierdza, że: „rodzina naszych czasów jest jak statek, który znalazł się w zasięgu burzy, ale mimo to płynie nadal - z nadłamanym masztem i wodą $\mathrm{w}$ swych najgłębszych czeluściach. I nikt nie jest w stanie ze stuprocentową pewnością powiedzieć, że statek dopłynie do portu"29. Wpływ na zjawisko kryzysu rodziny mają zmiany o charakterze zarówno społeczno-kulturowym, jak i politycznym. Coraz częściej poddaje się w wątpliwość samą ideę i instytucję rodziny jako środowiska wychowawczego, a nawet samej prokreacji. Podobnie deprecjonowana jest wartość nierozerwalności i trwałości instytucji małżeństwa i rodziny. Nietrudno zauważyć, że te liberalne wzorce małżeństwa i rodziny stoją w opozycji do stanowiska Kościoła w tej kwestii. Argumenty Kościoła katolickiego o nierozerwalności i monogamiczności małżeństwa, na którym opiera się instytucja rodziny, odwołują się do prawa naturalnego wpisanego w ludzką naturę. Kościół w swoim

${ }_{27}$ S. Styrna, Znaczenie wychowania w rodzinie dla rozwoju osobowego dziecka, [w:] F. Adamski (red.), Wychowanie w rodzinie chrześcijańskiej, Kraków 1982, s. 115.

${ }^{28}$ M.A. Krąpiec, O ludzka politykę, Katowice 1993, s. 66.

29 Z. Tyszka, Rodzina we współczesnym świecie, Poznań 2002, s. 184. 
nauczaniu stara się odczytywać naturę ludzką, korzystając przy tym z dorobku wielu dyscyplin naukowych, takich jak: filozofia, medycyna, psychologia, pedagogika, socjologia itp. Przypomina także, iż tak ujmowane małżeństwo i rodzina na trwałe weszły do cywilizacji łacińskiej, na której zbudowana jest kultura europejska ${ }^{30}$.

Nauczanie Kościoła jednoznacznie dowartościowuje rodzinę jako środowisko wychowawcze. Stanowczo podkreśla, że prawo rodziców do wychowania swoich dzieci wynikające $\mathrm{z}$ natury rodziny ma charakter prymarny wobec prawa stanowionego ${ }^{31}$. Zwraca uwagę, że w pracy opiekuńczo-wychowawczej rodziców (opiekunów-wychowawców) chodzi o odnalezienie pewnej równowagi pomiędzy naturalnym dążeniem dziecka do własnej autonomii, samodzielności a pozostawaniem w przestrzeni racjonalnej zależności od rodziców. Rodzina staje się środowiskiem budowania własnej podmiotowości. Ze sposobu funkcjonowania rodziny, gdzie dziecko uczy się zaufania, rodzi się u niego poczucie bezpieczeństwa. Ważne w tym względzie są relacje pomiędzy członkami rodziny, a zwłaszcza pomiędzy rodzicami. Mirosław Sobecki podkreśla, że w

świadomości młodego człowieka pojawia się kolejny bardzo ważny symbol - dom. W normalnie funkcjonujących rodzinach dom staje się ostoją bezpieczeństwa, egzystencjalnym oparciem na całe życie. Jednak w odróżnieniu od bardziej naturalnej relacji z matką wizja domu jest już bardziej kulturowa. Podstawowe zaufanie będzie związane z wizją domu zbudowaną na interakcjach w rodzinie. Kłopoty stąd wynikające pojawiają się nie tylko wówczas, kiedy po raz pierwszy na dłużej opuszczamy „nasz dom” i znajdujemy się w rodzących niepewność i lęk relacjach z innymi ludźmi, ale także wtedy, kiedy łączymy się z drugim człowiekiem tworząc małżeństwo, a następnie nową rodzinę. Wówczas to często spotykają się dwie wizje domu. Brak oparcia w rzeczywistości na wizji domu wyniesionej z dzieciństwa staje się źródłem egzystencjalnych napięć, prowadzących w skrajnych przypadkach do rozpadu związku ${ }^{32}$.

Dziecko przez rodzinę jako najbliższy mu krąg środowiskowy wrasta w kulturę własnego społeczeństwa.

Rodzina pełni w rozwoju dziecka bardzo ważną funkcję socjalizacyjną. Socjalizacja rozwija i ugruntowuje kompetencje człowieka, pozwala także zachować trwałość, a równocześnie kształtować zmianę struktur społecznych. Umożliwia ona dziecku, młodemu człowiekowi uczestnictwo w życiu społecznym i kulturalnym oraz kreowanie własnego życia. W przekonaniu Barbary Smolińskiej-Theiss

${ }^{30}$ B. Stańkowski, Zacznijmy od człowieka. Pedagogika w poszukiwaniu nowych kontekstów dla integracji i rozwoju społeczno-kulturowego, Kraków 2014, s. 86-87.

${ }_{31}$ A.J. Sobczyk, Rodzina chrześcijańska w nauczaniu papieża Franciszka, „Teologia i Moralność” 2014, nr 2 (16), s. 203.

${ }^{32}$ M. Sobecki, Tożsamość społeczno-kulturowa w perspektywie egzystencjalnej. Kontekst edukacji międzykulturowej, „Pedagogika Społeczna” 2019, nr 3 (73), s. 205. 
socjalizacja jest najczęściej łączona z różnymi interakcjami, w które wchodzi człowiek. W wyniku tych relacji jednostka buduje poczucie własnej tożsamości i zdolność do samodzielnego myślenia i działania. Socjalizacja kształtuje indywidualność człowieka, poczucie jego wolności, jak również pewien przymus społeczny, normę czy przyzwyczajenie. „Różne strony tego samego procesu, które prowadzą do ukształtowania się tożsamości indywidualnej i społecznej. W rezultacie można powiedzieć, że człowiekowi przypisuje się określone cechy, atrybuty wynikające z przynależności do określonej grupy, pełnienia określonej roli. Tworzona przez socjalizację tożsamość społeczna jednostki - $\mathrm{z}$ jednej strony, buduje określone oczekiwania, jakie środowisko stawia młodemu człowiekowi. Z drugiej strony, także odpowiada na te oczekiwania, wpisuje się w nie, interioryzuje, traktuje jako własne"33. W ramach tego permanentnego dialogu ze światem zewnętrznym człowiek kształtuje poczucie bycia sobą, indywidualną tożsamość.

Socjalizacja więc odnosi się do procesu włączania jednostki w coraz liczniejsze i bardziej zróżnicowane zbiorowości społeczne oraz przyjmowania przez nią charakterystycznych dla tych zbiorowości ról społecznych. W konsekwencji prowadzi to do ukształtowania społecznie pożądanych i akceptowanych cech osobowości. Treścią procesu socjalizacyjnego są wartości, aspiracje, normy i wzory regulujące zachowania, jak też wiedza o otaczającej rzeczywistości. Przebieg i treść analizowanego procesu wyznaczają z kolei „znaczący inni”, tj. osoby, które pośredniczą w przekazywaniu wiedzy niezbędnej do aktywnego uczestnictwa w życiu społecznym, np. rodzice, osoby sprawujące opiekę nad dzieckiem. „Osoby »znaczące« $\mathrm{w}$ procesie przekazywania dziedzictwa kulturowego i wiedzy o otaczającej rzeczywistości społecznej dokonują selekcji, wyboru, interpretacji i wartościowania przekazywanych treści. Selekcja i interpretacja zależą od miejsca w strukturze spolecznej osoby "znaczącej« oraz od cech jej osobowości" ${ }^{34}$.

Stanisław Kawula podkreśla, że człowiek ze swej natury jest istotą rodzinną i już na etapie rozwoju embrionalnego ma optymalne warunki rozwoju biologicznego w owodni i łożysku matki. Rzecz w tym, aby następnie w swoim życiu jednostkowym ukształtować równie korzystne warunki, tzw. „łożysko społeczne”. Oznacza to, że człowiek przychodzi na świat z określonymi potrzebami biologicznymi, natomiast jego potrzeby społeczno-kulturowe są nabyte $\mathrm{w}$ wyniku rozwoju osobowego, jego wrastania w społeczeństwo i wprowadzania w kulturę. Przywołany autor zaznacza, że współczesny nurt psychologii rozwojowej wyprowadza przesłanki do wspomagania rozwoju człowieka $\mathrm{z}$ fundamentalnych praw ludzkiego

${ }_{33}$ B. Smolińska-Theiss, Dzieciństwo jako status społeczny. Edukacyjne przywileje dzieci klasy średniej, Warszawa 2014, s. 150.

${ }_{34}$ B. Zięba, Zakres funkcji socjalizacyjno-wychowawczej rodziny, „Ruch Prawniczy, Ekonomiczny i Socjologiczny" 1989, nr 4, s. 348. 
$\dot{z ̇ y c i a}^{35}$. Chodzi tu zatem o stymulowanie i aktywizowanie relacji jednostki z układami biologicznymi, socjologicznymi i kulturowymi. Jak przekonuje Wiesław Theiss, proces uaktywniania właściwych i pozytywnych relacji psychospołecznych ma swój początek w rodzinie własnej, a następnie podlega rozszerzaniu przez inne, coraz szersze kręgi środowiskowe ${ }^{36}$.

\section{Wsparcie rodziny oparte na zasadzie pomocniczości}

Jan Paweł II, analizując problemy współczesnej rodziny, podkreśla znaczenie wzajemnej zależności rodziny i państwa. Podstawą tej relacji jest zasada subsydiarności. Papież zaznacza, że rodzina jest taką społecznością, która nie posiada wszystkich środków nieodzownych do realizacji własnych celów, przede wszystkim w zakresie wykształcenia i wychowania. W związku z tym ,wszędzie tam, gdzie rodzina jest samowystarczalna, należy ją pozostawić samej sobie; co więcej, interwencjonizm państwowy byłby w tym zakresie szkodliwy, byłby wyrazem nie poszanowania, a deptania praw rodziny. Pomoc państwa zaczyna się dopiero tam, gdzie rodzina naprawdę sobie nie wystarcza" ${ }^{37}$. Kierując się tą zasadą należy stwierdzić, że państwo nie powinno wyręczać rodziny w wypełnianiu zadań wynikających z jej natury i powołania oraz jej praw. Natomiast obowiązkiem państwa jest wsparcie rodziny, aby stawała się ona społecznością podmiotową i suwerenną. Papież podkreśla, że państwo jest zobligowane do respektowania praw człowieka, a tym samym praw rodziny. Uważa rodzinę za najistotniejszą wartość w europejskim i chrześcijańskim systemie prawnym. Przypomina, że przez dwa tysiące lat chrześcijaństwa cała europejska kultura uznawała rodzinę za fundamentalną instytucję każdego społeczeństwa. Pomoc państwa powinna polegać na stworzeniu takich warunków, które nie będą burzyły jedności rodziny, lecz będzie ona stawać się prawdziwym „siedliskiem sprawiedliwości i miłości” ${ }^{38}$. Ponadto państwo ma obowiązek troszczyć się o ład moralny, który będzie pomagał budować jedność rodziny, a przez to jedność społeczeństwa.

W KPR znalazły się zapisy dotyczące zapewnienia rodzinom odpowiednich warunków moralnych, wychowawczych, społecznych i ekonomicznych. Karta wyraźne podkreśla prawo rodziców do wychowania dzieci zgodnie ze swoimi przekonaniami moralnymi i religijnymi, z uwzględnieniem tradycji kulturowych rodziny, a także do decydowania o edukacji dzieci. Wskazuje się na swobodę or-

35 S. Kawula, Pedagogika społeczna dzisiaj i jutro, Toruń 2012, s. 152.

36 W. Theiss, Szkoła i edukacja środowiskowa, „Wychowanie na co Dzień” 1999, nr 1-2, s. 3-4.

37 Jan Paweł II, List do Rodzin, op. cit., s. 19.

38 Jan Paweł II, Pielgrzymka Jana Pawła II do Polski. Przemówienia, dokumentacja, PoznańWarszawa 1979, s. 110. 
ganizacji życia religijnego w środowisku domowym, publicznego wyrażania swojej wiary oraz zrzeszania się z innymi rodzinami. Dokument odnosi się także do kwestii materialnych związanych z funkcjonowaniem rodzin. Wskazuje na konieczność zapewnienia odpowiedniego wynagrodzenia za wykonywaną pracę, wsparcia finansowego oraz zapewnienia odpowiednich warunków mieszkaniowych. Jan Paweł II zachęcał władze państwowe, aby prowadząc swoją politykę uwzględniały realne potrzeby rodziny w celu budowania społecznej wspólnoty. Mówił: „Państwo jest istotnie suwerenne, jeśli rządzi społeczeństwem i zarazem służy dobru wspólnemu społeczeństwa i jeśli pozwala narodowi realizować właściwą mu podmiotowość, właściwą mu tożsamość. To pociąga za sobą między innymi stwarzanie odpowiednich warunków rozwoju w zakresie kultury, ekonomii i innych dziedzin życia społecznej wspólnoty"39.

Kościół zatroskany o kondycję współczesnej rodziny widzi konieczność wparcia i dopełnienia jej wysiłków na polu wychowania. Odwołując się do poglądów Wolfganga Brezinki, można mówić o pewnych formach „wsparcia moralnego”. Takie wsparcie oznaczałoby „dodanie rodzicom odwagi, by zdali sobie sprawę z własnych przekonań normatywnych i żyli zgodnie z nimi” ${ }^{40}$. Przywołany tu autor stawia następującą diagnozę: „Większość rodziców nie czuje się w sumieniu związana poprzez moralną tradycję grupy, do której należy, i nie uznaje też już żadnych moralnych autorytetów. (...) Poprzez swoje zdezorientowanie doprowadzają oni niechcący do niebezpiecznej sytuacji swoje dzieci, pozostające bez dobrego nastawienia do wartości i stające się moralnymi nihilistami” ${ }^{41}$. Dlatego Kościół w swoim nauczaniu mówiąc o wspomaganiu rodziny w jej pracy wychowawczej kładzie duży nacisk na edukację i formację młodych ludzi przygotowujących się do małżeństwa. W tym przygotowaniu widzi właściwy moment i miejsce do wprowadzania przyszłych małżonków w dialog, który w małżeństwie i rodzinie odgrywa zasadniczą rolę ${ }^{42}$.

Oprócz dziedziny wychowania i oświaty na różnych poziomach, pomoc państwa - nie wykluczając inicjatyw prywatnych - wyraża się poprzez instytucje mające na celu ochronę życia i zdrowia obywateli, a zwłaszcza w podejmowaniu odpowiednich środków dotyczących świata pracy. Bezrobocie stanowi w naszych czasach jedno z najpoważniejszych zagrożeń dla życia rodzinnego i staje się troską społeczeństw. Jest ono wyzwaniem dla polityki poszczególnych państw i przedmiotem dogłębnej refleksji dla nauki społecznej Kościoła. Znalezienie właściwych rozwiązań jest w tej dziedzinie nieodzowne - rozwiązań, które wznosząc się nawet ponad granice włas-

\footnotetext{
39 Jan Paweł II, Druga pielgrzymka Jana Pawła II do Polski, Poznań-Warszawa 1984, s. 69.

${ }^{40}$ W. Brezinka, Wychowywać dzisiaj. Zarys problematyki, Kraków 2007, s. 195.

${ }^{41}$ Ibidem, s. 196.

${ }^{42}$ K. Frejusz, Wychowanie jako „dialog i spotkanie” w myśli pedagogicznej Janusza Tarnowskiego. Studium hermeneutyczno-krytyczne, Warszawa 2020, s. 299.
} 
nego państwa, potrafią wyjść naprzeciw oczekiwaniom tak wielu rodzinom, dla których brak pracy oznacza dramatyczny stan skrajnej biedy. Mówiąc o pracy w odniesieniu do rodziny, trzeba podkreślić znaczenie i ciężar pracy kobiet wewnątrz rodziny. Praca ta powinna być gruntownie dowartościowana. Trud każdej kobiety związany z urodzeniem dziecka, opieką nad nim, wychowaniem, zwłaszcza w pierwszych latach, jest tak wielki, że nie może mu dorównać żadna praca zawodowa. Trzeba, ażeby fakt ten odzyskał należne zrozumienie w obrębie obowiązującego prawa pracy. Trzeba, ażeby macierzyństwo kobiet zostało zrozumiane jako wystarczający tytuł do odpowiedniego wynagrodzenia, niezbędnego do utrzymania rodziny w tej bardzo ważnej fazie jej egzystencji. Widać jak bardzo rodzina musi być wspomagana, aby mogła być faktycznie uznana za społeczność podstawową i w pewnym sensie „suwerenną”. „Suwerenność” jej jest jednak nieodzowna dla dobra społeczeństwa. Naród prawdziwie suwerenny i duchowo mocny jest zawsze złożony z mocnych rodzin: rodzin świadomych swojego powołania i posłannictwa w dziejach. W centrum tych wszystkich spraw i zadań stoi zawsze rodzina. Jakiekolwiek odsunięcie jej na dalszy plan, wycofanie z przysługującej jej w społeczeństwie pozycji, musi oznaczać niszczenie autentycznej substancji społecznej ${ }^{43}$.

Konstytucja RP w artykule 71 stwierdza, że: 1. „Państwo w swojej polityce społecznej i gospodarczej uwzględnia dobro rodziny. Rodziny znajdujące się w trudnej sytuacji materialnej i społecznej, zwłaszcza wielodzietne i niepełne, mają prawo do szczególnej pomocy ze strony władz publicznych. 2. Matka przed i po urodzeniu dziecka ma prawo do szczególnej pomocy władz publicznych, której zakres określa ustawa" ${ }^{34}$. Wsparcie i pomoc państwa nie powinny ograniczać się jedynie do obszaru kształcenia i wychowania, na co zwracał uwagę Jan Paweł II. Obowiązkiem państwa jest także popieranie takich inicjatyw o charakterze społecznym, politycznym, gospodarczym, kulturalnym czy pedagogicznym, które będą pomocą dla rodzin w wypełnianiu ich zadań. Dokonując syntezy nauczania Jana Pawła II w kontekście relacji państwa do rodziny, można uznać, że:

- obowiązkiem państwa jest zaakceptowanie rodziny jako wspólnoty osób, pełniącej określone funkcje, w których nikt nie może jej zastąpić;

- rodzina jest podstawową wartością, co wiąże się z akceptacją jej przynależnych praw, które są pierwotne i nienaruszalne;

- państwo ma obowiązek prowadzić politykę prorodzinną;

- państwo powinno respektować prawa rodziny, które będą uwzględniały potrzeby tej wspólnoty osób w ustawodawstwie, polityce społecznej i ekonomicznej;

${ }^{43}$ Jan Paweł II, List do Rodzin, op. cit., s. 20.

${ }^{44}$ Konstytucja Rzeczypospolitej Polskiej, art. 71, https://www.sejm.gov.pl/prawo/konst/polski/ kon1.htm [dostęp: 23.08.2021]. 
- obowiązkiem państwa jest zapewnienie rodzinie konstytucyjnej ochrony, mając na względzie prawidłowy rozwój dzieci i dobro każdego członka rodziny;

- dzieci nie są własnością państwa, dlatego proces wychowania może odbywać się wyłącznie w porozumieniu $\mathrm{z}$ rodzicami i z ich mandatu na zasadzie subsydiarności;

- w sytuacji, gdy rodzina nie może samodzielnie poradzić sobie ze swoimi problemami, państwo ma obowiązek pomocy takiej rodzinie ${ }^{45}$.

Z nauczania papieża Jana Pawła II można wywnioskować, że istotną rolę w zakresie tworzenia warunków dla rozwoju i funkcjonowania rodzin odgrywa państwo, a w szczególności prowadzona przez władze polityka rodzinna. Jest ona długofalowym systemem celów i rozwiązań prawnych ukierunkowanych na wsparcie rodzin.

Polityka rodzinna określa zakres działań rządu, które mają na celu oddziaływanie na sytuację rodzin, a zwłaszcza rodzin $\mathrm{z}$ dziećmi. Jednym $\mathrm{z}$ podstawowych założeń tej polityki jest kreowanie warunków sprzyjających prawidłowemu funkcjonowaniu rodzin poprzez podejmowanie działań, które doprowadzą do poprawy warunków ich życia, co w dłuższej perspektywie ma przyczyniać się do rozwoju społeczeństwa i osiągnięcia pożądanych zmian jego struktury ${ }^{46}$.

Jednym z podstawowych narzędzi polityki rodzinnej jest bezpośrednie świadczenie pieniężne skierowane do rodzin. W 2015 r. po przejęciu w Polsce władzy przez zjednoczoną prawicę, która w swoich programach społeczno-politycznych odwołuje się do społecznej nauki Kościoła, zostały wprowadzone nowe świadczenia pieniężne na rzecz rodzin. Nad tymi rozwiązaniami w polskim społeczeństwie toczy się ożywiona dyskusja dotycząca celowości ich wprowadzenia i skutków dla budżetu państwa, jakie ze sobą niosą. Znaczący wzrost wydatków z budżetu państwa na świadczenia rodzinne nastąpił w 2016 roku, czyli od momentu wprowadzenia programu Rodzina 500 plus $^{47}$. Wydaje się, iż polityka rodzinna państwa jest w dużej mierze zbieżna $\mathrm{z}$ nauczaniem Kościoła, który stoi na stanowisku, że nie ma lepszej drogi odbudowy społeczeństwa jako wspólnoty, jak jego odrodzenie przez silne i zdrowe rodziny. Ponieważ rodzina jest pierwszą szkołą autentycznych postaw społecznych każdego społeczeństwa.

${ }^{45}$ D. Bondyra, Obowiązki państwa wobec rodziny w nauczaniu Jana Pawła II, [w:] J. Wilk (red.), Społeczna troska o dziecko w XX wieku, Lublin 2003, s. 337-338.

${ }^{46} \mathrm{M}$. Wojciuk, Rola świadczeń rodzinnych $w$ polskiej polityce rodzinnej, https://repozytorium. uwb.edu.pl/jspui/bitstream/11320/9279/1/M_Wojciuk_Rola_swiadczen_rodzinnych_w_polskiej_ polityce_rodzinnej (1).pdf, s. 109 [dostęp: 16.09.2021].

${ }^{47}$ Ibidem, s. 110. 


\section{Podsumowanie}

To oczywiste, że katalog zagadnień wymienionych w tym tekście jest niepełny i pozostaje otwarty. Wskazane zostały jedynie te problemy zawarte w KPR, które w mojej opinii są dzisiaj najbardziej palące. Podjęto tutaj próbę ukazania, że KPR jest niezwykle ważnym dokumentem, który wskazuje kierunek (prze)budowy systemu prawnego i mentalnego społeczeństwa w podejściu do instytucji rodziny w świetle społecznej nauki Kościoła. Skrupulatna i refleksyjna lektura KPR może pomóc współczesnemu człowiekowi zauważyć zarówno dysonans pomiędzy obowiązkiem a samowolą, który charakteryzuje dzisiejsze podejście do ludzkich praw, jak również dogłębne wymaganie przezwyciężenia takiego dysonansu przy pomocy uczciwej i pogłębionej refleksji.

Jak podkreślił to S. Kawula, człowiek jest istotą rodzinną, dlatego przede wszystkim w rodzinie kształtuje własną tożsamość psychiczną, moralną, kulturalną, językową, społeczną, związaną z relacjami międzyludzkimi. Aby osiągnąć ten cel kształtowania poszczególnych osobowych tożsamości w odniesieniu do pokoleń, rodzina potrzebuje uznania i akceptacji swojej tożsamości. W preambule KPR jest mowa o tym, że rodzina „stanowi wspólnotę miłości i solidarności, jedyną pod względem możliwości nauczania i przekazywania wartości kulturalnych, etycznych, społecznych, duchowych i religijnych, istotnych dla rozwoju i powodzenia

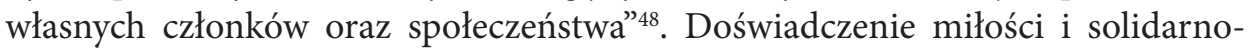
ści należy do najbardziej osobistych i obiektywnych zjawisk, których nie da się sprowadzić do subiektywnych, ulotnych i niepodlegających ocenie doświadczeń. Miłość i solidarność konfrontują człowieka z jego odpowiedzialnością, która jest węzłem, spoiwem relacji międzyosobowych, a tego nie da się arbitralnie i subiektywnie zrzec czy $\mathrm{z}$ tego zrezygnować. $\mathrm{Z}$ tego też powodu rodzina ma podstawowe prawa, a poszczególne osoby mają wobec rodziny obowiązki, od których nie można uciec. Ostatecznie nie da się rozmyć praw i obowiązków płynących z miłości i solidarności, a świat bez nich staje się ułudą. Uważnego czytelnika Karta Praw Rodziny będzie prowokować i niepokoić, a pożytek osiągnięty z tej lektury przyniesie mu określoną korzyść psychologiczną, kulturalną, moralną i religijną.

\section{Bibliografia}

Bondyra D., Obowiązki państwa wobec rodziny w nauczaniu Jana Pawła II, [w:] J. Wilk (red.), Społeczna troska o dziecko $w$ XX wieku, Lublin 2003.

Brezinka W., Wychowywać dzisiaj. Zarys problematyki, Kraków 2007.

Christine de Marcellus Vollmer, President, Latin American Alliance for the Family, https://doc-research.org/speaker/christine-de-marcellus-vollmer/ [dostęp: 06.10.2021].

${ }^{48}$ Karta Praw Rodziny, op. cit., s. 14-15. 
Deklaracja o wychowaniu chrześcijańskim, [w:] Sobór Watykański II. Konstytucje, dekrety, deklaracje, Poznań 1967.

Franciszek, Encyklika Lumen fidei, Rzym 2013, https://www.vatican.va/content/dam/francesco/ pdf/encyclicals/documents/papa-francesco_20130629_enciclica-lumen-fidei_pl.pdf [dostęp: 31.08.2021].

Franciszek, Solidarność między pokoleniami. Przesłanie z okazji 47. Tygodnia Społecznego Katolików Włoskich, „L'Osservatore Romano” 2013, nr 11 (34), s. 33-34.

Franciszek, W rodzinie uczymy się kochać i bronić życia. Audiencja dla uczestników zgromadzenia plenarnego Papieskiej Rady ds. Rodziny z 25 października 2013 r., „L’Osservatore Romano” 2013, nr 12 (34), s. 27-29.

Frejusz K., Wychowanie jako „dialog i spotkanie” w myśli pedagogicznej Janusza Tarnowskiego. Studium hermeneutyczno-krytyczne, Warszawa 2020.

Gaudium et spes, [w:] Sobór Watykański II. Konstytucje, dekrety, deklaracje, Poznań 1967.

Jan Paweł II, Druga pielgrzymka Jana Pawła II do Polski, Poznań-Warszawa 1984.

Jan Paweł II, Familiaris consortio, [w:] T. Styczeń (red.), Tekst i komentarze, Lublin 1987.

Jan Paweł II, List do Rodzin, Rzym 1994, http://kodr.pl/wp-content/uploads/2017/03/list_do_rodzin. pdf [dostęp: 30.08.2021].

Jan Paweł II, Pielgrzymka Jana Pawła II do Polski. Przemówienia, dokumentacja, Poznań-Warszawa 1979.

Karta Praw Rodziny. Prezentacja, interpretacja i komentarz J.E. Biskup Vincenzo Paglia - przewodniczący Papieskiej Rady ds. Rodziny, Pelplin 2013.

Kawula S., Pedagogika społeczna dzisiaj i jutro, Toruń 2012.

Konstytucja Rzeczypospolitej Polskiej, https://www.sejm.gov.pl/prawo/konst/polski/kon1.htm [dostęp: 23.08.2021].

Krąpiec M.A., O ludzką politykę, Katowice 1993.

Mierzwiński B., Quo vadis familia? Cywilizacja śmierci zagrożeniem rodziny i społeczeństwa, [w:] M. Ozorowski, A. Skreczko (red.), Kościót. Rodzina. Życie, Warszawa 2011.

Powszechna Deklaracja Praw Człowieka, https://www.unesco.pl/fileadmin/user_upload/pdf/Powszechna_Deklaracja_Praw_Czlowieka.pdf [dostęp: 16.08.2021].

Rezolucja Sejmu Rzeczypospolitej Polskiej z dnia 27 października 1994 r. w sprawie Międzynarodowego Roku Rodziny, https://sip.lex.pl/akty-prawne/mp-monitor-polski/miedzynarodowy-rok-rodziny-16824844 [dostęp: 14.09.2021].

Smolińska-Theiss B., Dzieciństwo jako status społeczny. Edukacyjne przywileje dzieci klasy średniej, Warszawa 2014.

Sobczyk A.J., Rodzina chrześcijańska w nauczaniu papieża Franciszka, „Teologia i Moralność” 2014, nr 2 (16), s. 201-214.

Sobecki M., Tożsamość społeczno-kulturowa w perspektywie egzystencjalnej. Kontekst edukacji międzykulturowej, „Pedagogika Społeczna” 2019, nr 3 (73), s. 201-211.

Stańkowski B., Zacznijmy od człowieka. Pedagogika w poszukiwaniu nowych kontekstów dla integracji i rozwoju społeczno-kulturowego, Kraków 2014.

Stelmachowski A., Karta Praw Rodziny, [w:] K. Majdański (red.), Tak - życiu, tak - prawdzie, Łomianki 1991, s. 21.

Styrna S., Znaczenie wychowania w rodzinie dla rozwoju osobowego dziecka, [w:] F. Adamski (red.), Wychowanie w rodzinie chrześcijańskiej, Kraków 1982.

Theiss W., Szkoła i edukacja środowiskowa, „Wychowanie na co Dzień” 1999, nr 1-2, s. 3-5. 
Tyszka Z., Rodzina we wspótczesnym świecie, Poznań 2002.

Tyszka Z., System metodologiczny wieloaspektowej integralnej analizy życia rodzinnego, Poznań 2001.

Uchwała Sejmu Rzeczypospolitej Polskiej z dnia 21.10.2016 r. w sprawie ustanowienia Dnia Praw Rodziny, http://isap.sejm.gov.pl/isap.nsf/download.xsp/WMP20160001003/O/M20161003.pdf [dostęp: 6.10.2021].

Wojciuk M., Rola świadczeń rodzinnych w polskiej polityce rodzinnej, https://repozytorium.uwb.edu. pl/jspui/bitstream/11320/9279/1/M_Wojciuk_Rola_swiadczen_rodzinnych_w_polskiej_polityce_rodzinnej (1).pdf [dostęp: 16.09.2021].

Wojtyła K. Rodzina jako „communio personarum”. Próba interpretacji teologicznej, „Ateneum Kapłańskie" 1974, nr 66 (83), s. 347-361.

Zięba B., Zakres funkcji socjalizacyjno-wychowawczej rodziny, „Ruch Prawniczy, Ekonomiczny i Socjologiczny" 1989, nr 4, s. 343-355. 